\title{
ESTIMATION OF LEAF AREA OF Erythroxylum citrifolium FROM LINEAR LEAF DIMENSIONS
}

\author{
ESTIMATIVA DA ÁREA FOLIAR DE Erythroxylum citrifolium A PARTIR DE \\ DIMENSÕES LINEARES DA FOLHA
}

\section{João Everthon da Silva RIBEIRO ${ }^{1, *} ;$ Ester dos Santos COÊLHO ${ }^{1}$; Francisco Romário Andrade FIGUEIREDO ${ }^{2}$; Sérgio de Faria LOPES $^{3}$; Manoel Bandeira de ALBUQUERQUE ${ }^{1}$}

1. Universidade Federal da Paraíba, Centro de Ciências Agrárias, Areia, Paraíba, Brasil. j.everthon@hotmail.com*; 2. Universidade Federal Rural do Semi-Árido, Mossoró, Rio Grande do Norte, Brasil; 3. Universidade Estadual da Paraíba, Departamento de Biologia, Campina Grande, Paraíba, Brasil.

\begin{abstract}
Erythroxylum citrifolium is a neotropical plant species recorded in all regions of Brazil. Determining leaf area is of fundamental importance to studies related to plant propagation and growth. The objective was to obtain an equation to estimate the leaf area of $E$. citrifolium from linear dimensions of the leaf blade (length and width). A total of 200 leaf blades were collected in Parque Estadual Mata do Pau-Ferro in the municipality of Areia, state of Paraíba, Northeast Brazil. The models evaluated were: linear, linear without intercept, quadratic, cubic, power and exponential. The best model was determined by the criteria of: high coefficient of determination $\left(\mathrm{R}^{2}\right)$, low root mean square error (RMSE), low Akaike information criterion (AIC), high Willmott concordance index $(d)$ and a BIAS index close to zero. All of the models constructed satisfactorily estimated the leaf area of E. citrifolium, with coefficients of determination above 0.9050 , but the power model using the product between length and width $(\mathrm{L} * \mathrm{~W}) \hat{\mathrm{y}}=0.5966^{*} \mathrm{LW}^{1.0181}$ was the best, with the highest values of $\mathrm{R}^{2}$ and $d$, low values of RMSE and AIC, and a BIAS index closest to zero.
\end{abstract}

KEYWORDS: Biometry. Non-destructive method. Allometric equations. Erythroxylaceae.

\section{INTRODUCTION}

Erythroxylum citrifolium A.St.-Hil. (Erythroxylaceae), commonly known as cumixá, is a Neotropical plant species distributed throughout Central and South America from Mexico to Southern Brazil, with records in all regions of Brazil (PLOWMAN; HENSOLD, 2004; LOIOLA et al., 2007). It is found in the most varied types of vegetation, but mainly in remnants of humid forests of the Atlantic Forest biome and in mountain forests known as Brejos de Altitude (LOIOLA; COSTALIMA, 2015). This species is used as a medicinal plant and has anti-inflammatory properties for the treatment of bronchitis and other respiratory diseases (GONZÁLEZ-GUEVARA et al., 2004). The branches and leaves have several pharmacological substances, including an important antimicrobial that may help in the treatment of herpes simplex virus type 1 (HSV-1) and human immunodeficiency virus (HIV) (HOZUMI et al., 1995; MATSUSEA et al., 1999; GONZÁLEZGUEVARA et al., 2004; DAN; CASTELLAR, 2015).

Due to the importance of this species, are increasingly needed physiological studies related to the parameters of plant growth, development and productivity. Among these studies, the measurement of leaf area is fundamental, and perhaps the most important parameter in the evaluation of plant growth and development (CANDIDO et al., 2013). However, leaf area is a difficult variable to measure due to the fact that it requires the use of expensive devices and destructive methods (CARGNELUTTI FILHO et al., 2015a).

Leaf area can be determined by direct or indirect methods, which are classified as destructive and non-destructive respectively (MALAGI et al., 2010). Destructive methods are simple and precise, but require a lot of time and cause the total destruction of vegetal mass (MOTA et al., 2014). On the other hand, non-destructive methods allow for numerous evaluations of the same plant with speed and precision, and without destroying the sample (MOTA et al., 2014). One such indirect method is estimating leaf area by means of regression equations using actual leaf area as a function of leaf parameters (length and width), which are directly related to leaf surface (ZHANG; PAN, 2011). This non-destructive method has been used innumerous studies, both for cultivated species (POMPELLI et al., 2012; SILVA et al., 2013; FRANCISCO et al., 2014; BUTTARO et al., 2015; GANESHAMURTHY et al., 2016; OLIVEIRA et 
al., 2017; CARVALHO et al., 2017) and forest species (POMPELLI et al., 2012; SILVA et al., 2013; QUEIROZ et al., 2013; ASSIS et al., 2015; KERAMATLOU et al., 2015; RIBEIRO et al., 2018a; RIBEIRO et al., 2019). Thus, the objective was to obtain an equation for estimating the leaf area of Erythroxylum citrifolium from linear dimensional parameters of leaf blades.

\section{MATERIAL AND METHODS}

\section{Study area}
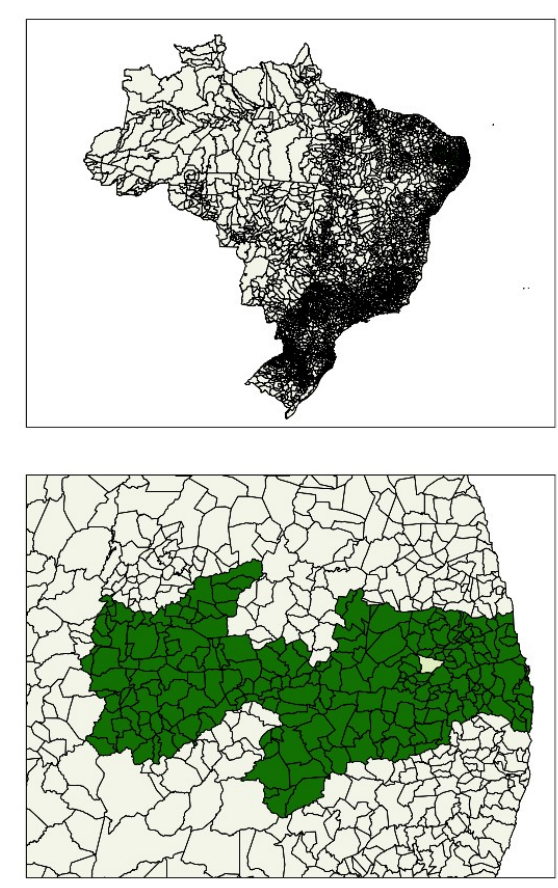

The study was undertaken in Parque Estadual Mata do Pau-Ferro, in the municipality of Areia located in the micro-region of Brejo and mesoregion of Agreste Paraibano, state of Paraíba (PB), Northeast Region of Brazil (6 $6^{\circ} 58^{\prime} 12^{\prime \prime} \mathrm{S}$ $35^{\circ} 42^{\prime} 15^{\prime} \mathrm{W}$ ) (Figure 1). The climate of the region is tropical and classified as Aw (PELL et al., 2007), which is characterized as hot and humid with autumn-winter rains. The mean annual temperature is $22^{\circ} \mathrm{C}$ and the mean annual rainfall is $1,400 \mathrm{~mm}$ (RIBEIRO et al., 2018b). The elevation of the region varies between 400 and 600 meters.

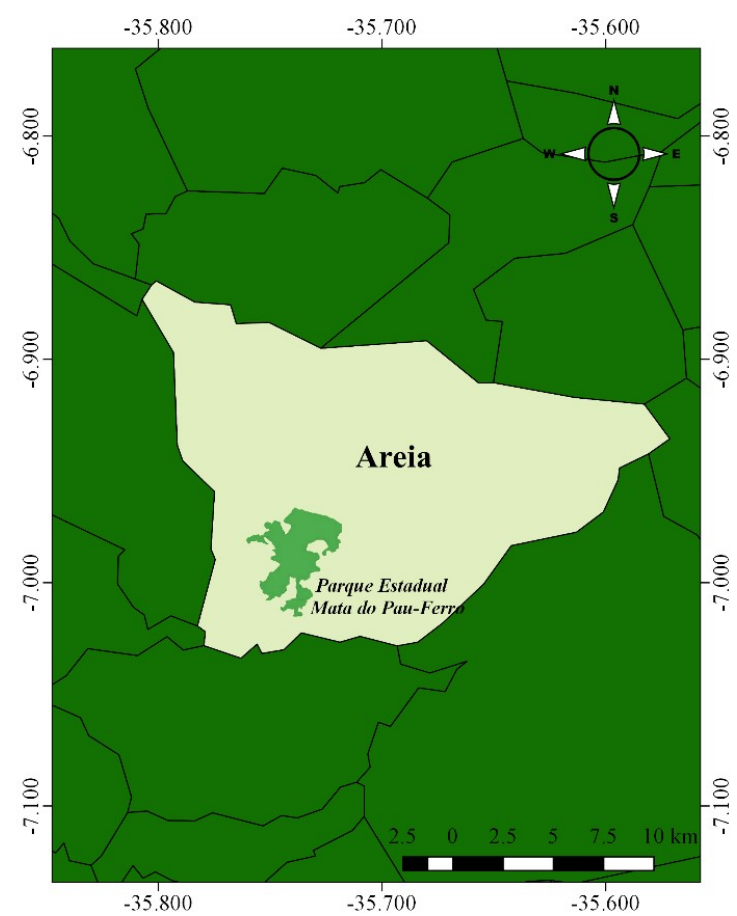

Figure 1. Geographic location of Parque Estadual Mata do Pau-Ferro, municipality of Areia, state of Paraíba Northeast Brazil.

\section{Data collection}

For the collection of leaf area data, 200 leaf blades of different shapes and sizes were selected from individual plants in a matrix of Erythroxylum citrifolium, considering only leaves that did not exhibit damage caused by external factors, such as climate, pests and diseases (SCHMILDT et al., 2014). The leaf blades were packed in a box with cold water to avoid water loss and taken to the Plant Ecology Laboratory (Universidade Federal da Paraíba). The length (L) and width (W) of each leaf blade (Figure 2) were measured using a graduated ruler, and their product calculated $\left(\mathrm{L}^{*} \mathrm{~W}\right)$. In order to determine true leaf area, the leaf blades were scanned with a reference scale, the images contrasted using the Image $J^{\circledR}$ Software and the true area of the leaf blades measured (JADOSKI et al. (2012).

To choose the best equation for estimating leaf area of E. citrifolium, regression studies were performed employing the following statistic models: linear $(\hat{y}=a+b x)$, linear without intercept $(\hat{y}=b x)$, quadratic $\left(\hat{y}=a+b x+c x^{2}\right)$, cubic $\left(\hat{y}=a+b x+c x^{2}\right.$ $\left.+d x^{3}\right)$, power $\left(\hat{y}=a x^{b}\right)$, and exponential $\left(\hat{y}=a b^{x}\right)$, in which the dependent variable $\hat{y}$ estimates leaf area (LA) as a function of $\mathrm{x}$ (length, width or the product between length and width). 


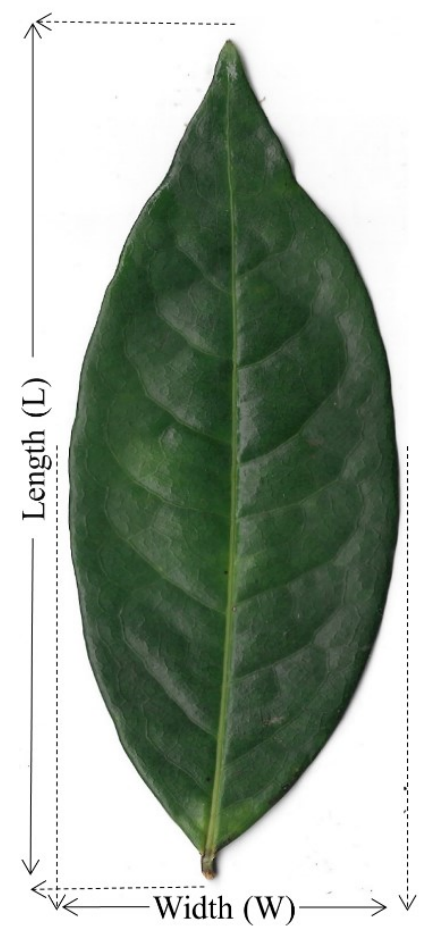

Figure 2. Length (L) and width (W) of a leaf blade of Erythroxylum citrifolium used for leaf area estimation.

The criteria used to choose the best model for estimating leaf area of E. citrifolium were the coefficient of determination $\left(\mathrm{R}^{2}\right)$, root mean square error (RMSE) (JANSSEN; HEUBERGER, 1995), Akaike Information Criterion (AIC) (FLORIANO et al., 2006), Willmott concordance index (d) (WILLMOTT et al., 1985), and BIAS index (LEITE; ANDRADE, 2002). The best model was considered the one with greatest values of $\mathrm{R}^{2}$ and $\mathrm{d}$, lowest values of RMSE and AIC, and a BIAS index closest to zero. The statistical analyses were

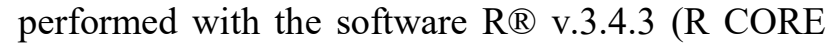

TEAM, 2018), using the 'hydroGOF' statistical package.

\section{RESULTS AND DISCUSSION}

The leaf blades of $E$. citrifolium varied in length (L) from 1.20 to $17.91(\mathrm{~cm})$, with a mean of $8.60 \mathrm{~cm}$, and width (W) from 0.43 to $6.13 \mathrm{~cm}$, with a mean of $2.82 \mathrm{~cm}$. True leaf area (LA) varied from 0.40 to $70.44 \mathrm{~cm}^{2}$ with a mean of $18.85 \mathrm{~cm}^{2}$ (Table 1).

Table 1. Minimum, maximum, median, standard deviation, standard error and coefficient of variation for length (L), width (W), the product between length and width (L*W) and leaf area (LA) of 200 leaf blades of Erythroxylum citrifolium,

\begin{tabular}{lcccc}
\hline Descriptive statistical & $\mathbf{L}(\mathbf{c m})$ & $\mathbf{W}(\mathbf{c m})$ & $\mathbf{L} * \mathbf{W}\left(\mathbf{c m}^{2}\right)$ & $\mathbf{L A}\left(\mathbf{c m}^{2}\right)$ \\
\hline Minimum & 1.20 & 0.43 & 0.62 & 0.40 \\
Maximum & 17.91 & 6.13 & 109.11 & 70.44 \\
Mean & 8.60 & 2.82 & 29.53 & 18.85 \\
Median & 8.00 & 2.68 & 21.62 & 13.58 \\
Standard deviation & 4.08 & 1.32 & 25.32 & 16.42 \\
Standard error & 0.29 & 0.09 & 1.79 & 1.16 \\
C.V. (\%) & 47.43 & 46.62 & 85.75 & 87.14 \\
\hline
\end{tabular}


Variation in the linear dimensions of $E$. citrifolium leaf blades showed that length and width had the low values for the coefficient of variation, while greater variability was observed for their product $(\mathrm{L} * \mathrm{~W})$ and leaf area (Table 1). This greater variability is fundamental for the elaboration of regression models that estimate leaf area from linear measurements because it allows applicability to leaves of different shapes and sizes (CARGNELUTTI FILHO et al., 2012). Other studies have likewise found greater variability for the product between length and width $(\mathrm{L} * \mathrm{~W})$ compared to length (L) and width (W) in leaves of
Canavalia ensiformis (TOEBE et al., 2012), Brassica napus (CARGNELUTTI FILHO et al., 2015a), Cajanus cajan (CARGNELUTTI FILHO et al., 2015b) and Passiflora edulis (SCHMILDT et al., 2016).

According to dispersion diagrams for length, width, product between length and width and leaf area of E. citrifolium, patterns of association of data adjusted by linear and non-linear models (Figure 3) can be observed corroborating other studies (CARGNELUTTI FILHO et al., 2012; CARGNELUTTI FILHO et al., 2015a, b).
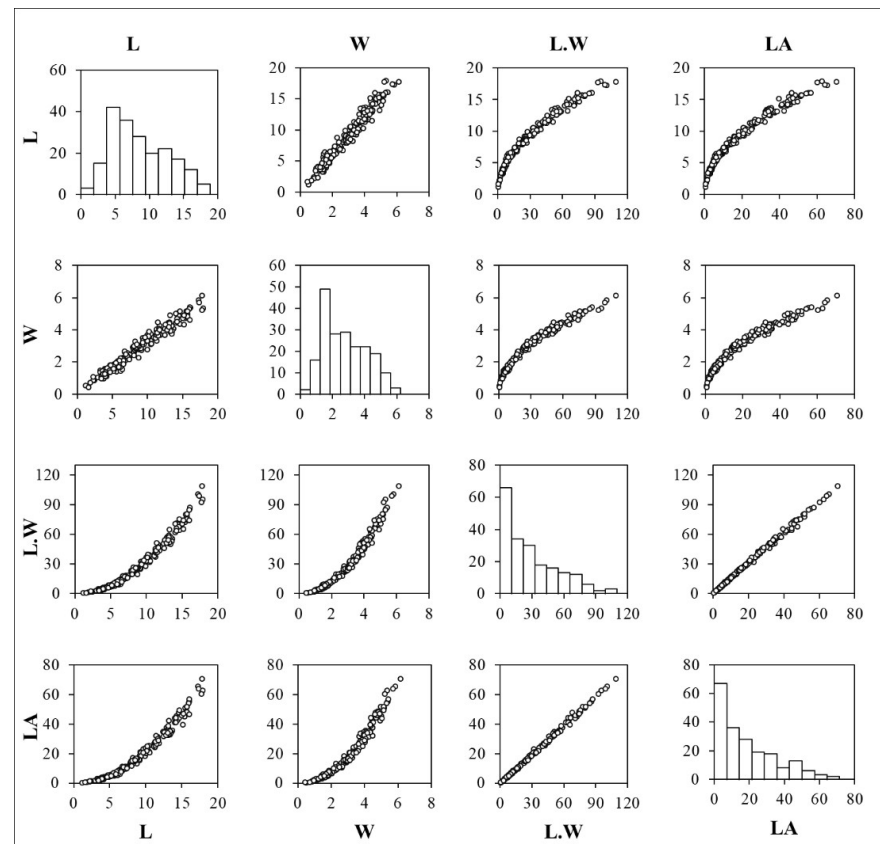

Figure 3. Frequency histogram and dispersion graph of length (L), width (W), product between length and width $\left(\mathrm{L}^{*} \mathrm{~W}\right)$ and true leaf area (LA), in 200 leaf blades of Erythroxylum citrifolium.

The equations obtained for the adjusted models relating true leaf area (LA) with length (L), width (W) and product between length and width $(\mathrm{L} * \mathrm{~W})($ Table 2$)$. All equations produce satisfactory estimations of E. citrifolium leaf area, since the coefficients of determination $\left(\mathrm{R}^{2}\right)$ were all above 0.905 (Table 2), indicating that at least $90.50 \%$ of the variation in E. citrifolium leaf area is explained by the proposed models using linear leaf blade parameters.

Comparing the equations that used $\mathrm{L}$ or $\mathrm{W}$, it is verified that the product dependencies between length and width $\left(\mathrm{L}^{*} \mathrm{~W}\right)$ are the most recommended for estimating leaf area, similar to that observed by Hinnah et al. (2014). Similar results have been recorded for other forest species, such as Amburana cearenses, Caesalpinia ferrea and Caesalpinia pyramidalis (SILVA et al., 2013), Acrocomia aculeata (MOTA et al., 2014) and Merremia aegyptia (ASSIS et al., 2015). Such results were also observed for cultivated species, such as Ananas comosus (FRANCISCO et al., 2014), Vigna unguiculata (OLIVEIRA et al., 2015), Prunus persica (SACHET et al., 2015), Smallanthus sonchifolius (ERLACHER et al., 2016) and Litchi chinensis (OLIVEIRA et al., 2017).

In general, the power model that used the product of length and width $(\mathrm{L} * \mathrm{~W})$ presented the highest values of $\mathrm{R}^{2}(0.9979)$ and $d(0.99950)$, lowest values of REMS (0.7506) and AIC (459.12), and a BIAS index of nearly zero $(-0.0012)$ (Table $2)$. Thus, based on the criteria adopted, the estimation of $E$. citrifolium leaf area can be performed by the equation $\hat{\mathrm{y}}=0.5966 * \mathrm{LW}^{1.0181}$. 
Low dispersion of the data can be seen in the adjustment curve, indicating that equation $(\hat{\mathrm{y}}=$ $\left.0.5966 * \mathrm{LW}^{1.0181}\right)$, can explain E. citrifolium leaf area satisfactorily (Figure $4 \mathrm{~A}$ and $\mathrm{B}$ ). The power model using the product $(\mathrm{L} * \mathrm{~W})$ has also been recommended for estimating the leaf area of other species, such as Styrax pohlii and Styrax ferrugineus (SOUZA et al., 2014), Vigna unguiculata (OLIVEIRA et al., 2015), Passiflora edulis (SCHMILDT et al., 2016), Crotalaria juncea
(CARVALHO et al., 2017), Urochloa mosambicensis (LEITE et al., 2017), and Psychotria carthagenensis and Psychotria hoffmannseggiana (RIBEIRO et al., 2019).

Overall, our results hold great potential for ecophysiological studies, especially for forest species, because they allow the monitoring of leaf area in a given place and time, and thus help to understand the growth patterns of plants.

Table 2. Equations for estimating leaf area $\left(\mathrm{cm}^{2}\right)$ of Erythroxylum citrifolium with determination coefficients $\left(\mathrm{R}^{2}\right)$, Akaike information criterion (AIC), root mean square error (RMSE), Willmott concordance index $(d)$ and BIAS index, using linear measures of length $(\mathrm{L})$, width $(\mathrm{W})$ and their product $\left(\mathrm{L}^{*} \mathrm{~W}\right)$.

\begin{tabular}{|c|c|c|c|c|c|c|c|}
\hline Model & $\mathbf{x}(1)$ & Equation & $\mathbf{R}^{2}$ & AIC & RMSE & $d$ & BIAS \\
\hline Linear & $\mathrm{L}$ & $\hat{y}=-14.8712+3.9194 * L$ & 0.9483 & 1099.4 & 3.723 & 0.9865 & 0.0052 \\
\hline Linear & $\mathrm{W}$ & $\hat{y}=-15.3209+12.1061 * W$ & 0.9408 & 1126.6 & 3.985 & 0.9845 & -0.0089 \\
\hline Linear & $\mathrm{L} * \mathrm{~W}$ & $\hat{y}=-0.2848+0.6480 * L W$ & 0.9979 & 463.0 & 0.758 & 0.9994 & 0.0022 \\
\hline Linear $(0.0)$ & $\mathrm{L} * \mathrm{~W}$ & $\hat{y}=0.6424 * L W$ & 0.9977 & 472.6 & 0.758 & 0.9994 & 0.0024 \\
\hline Quadratic & $\mathrm{L}$ & $\hat{y}=0.1976 * L^{2}+0.1859 * L-0.6537$ & 0.9873 & 820.2 & 1.843 & 0.9968 & 0.0024 \\
\hline Quadratic & $\mathrm{W}$ & $\hat{\mathrm{y}}=2.0132 * \mathrm{~W}^{2}-0.2615 * \mathrm{~W}+0.0799$ & 0.9840 & 866.6 & 2.070 & 0.9959 & 0.0029 \\
\hline Quadratic & $\mathrm{L} * \mathrm{~W}$ & $\hat{y}=0.0001 * L^{2}+0.6362 * L W-0.1475$ & 0.9979 & 461.9 & 0.752 & 0.9994 & 0.0020 \\
\hline Cubic & $\mathrm{L}$ & $\hat{y}=-0.0017 * L^{3}+0.2465 * L^{2}-0.2240 * \mathrm{~L}+0.3078$ & 0.9872 & 821.2 & 1.839 & 0.9968 & 0.0069 \\
\hline Cubic & $\mathrm{W}$ & $\hat{\mathrm{y}}=-0.0843 * \mathrm{~W}^{3}+2.8179 * \mathrm{~W}^{2}--2.5258 * \mathrm{~W}+1.8747$ & 0.9840 & 866.4 & 2.058 & 0.9960 & 0.0100 \\
\hline Cubic & $\mathrm{L} * \mathrm{~W}$ & $\hat{y}=-0.000002 * \mathrm{LW}^{3}+0.0005 * \mathrm{LW}^{2}+0.6208 * \mathrm{LW}-0.0392$ & 0.9979 & 462.8 & 0.751 & 0.9994 & 0.0015 \\
\hline Power & $\mathrm{L}$ & $\hat{y}=0.2210 * L^{1.9760}$ & 0.9873 & 818.6 & 1.845 & 0.9967 & -0.0414 \\
\hline Power & $\mathrm{W}$ & $\hat{y}=1.8780 * W^{2.0276}$ & 0.9840 & 864.9 & 2.071 & 0.9959 & -0.0198 \\
\hline Power & $\mathrm{L} * \mathrm{~W}$ & $\hat{y}=0.5966 * L^{1.0181}$ & 0.9979 & 459.1 & 0.750 & 0.9995 & -0.0012 \\
\hline Exponential & $\mathrm{L}$ & $\hat{y}=3.3942 * 1.1885^{L}$ & 0.9630 & 1051.3 & 3.301 & 0.9890 & -0.6126 \\
\hline Exponential & $\mathrm{W}$ & $\hat{y}=3.3715^{*} 1.7023^{W}$ & 0.9573 & 1081.1 & 3.557 & 0.9871 & -0.6760 \\
\hline Exponential & $\mathrm{L} * \mathrm{~W}$ & $\hat{\mathrm{y}}=8.7128 * 1.0220^{\mathrm{LW}}$ & 0.9051 & 1240.2 & 5.294 & 0.9695 & -0.9390 \\
\hline
\end{tabular}

(1) Linear dimensions: length (L) and width (W) 

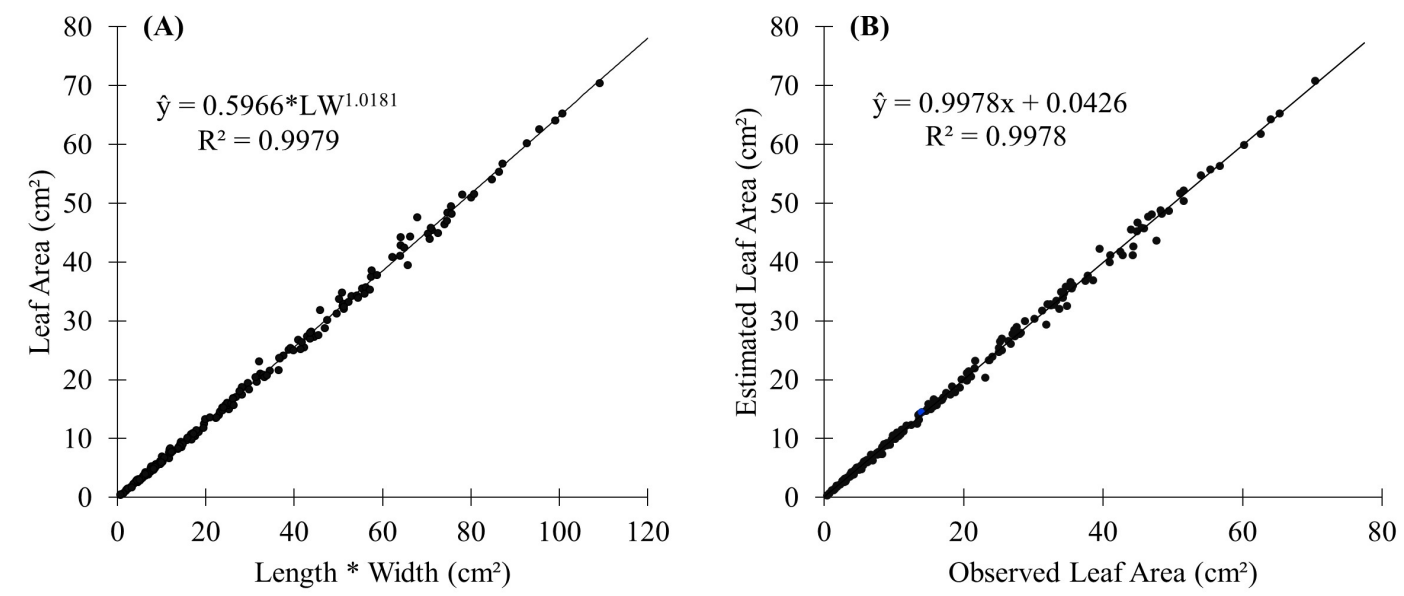

Figure 4. (A) True leaf area of Erythroxylum citrifolium as a function of the product of length and width (L*W) of leaf blades, according to the equation indicated for estimating the leaf area. (B) Relationship between true leaf area and leaf area estimated by the proposed equation.

\section{CONCLUSIONS}

The leaf area of E. citrifolium can be accurately estimated by the non-destructive method of using linear measurements of leaf blades.
The equations that used the product of length and width $\left(\mathrm{L}^{*} \mathrm{~W}\right)$ were the most successful at estimating E. citrifolium leaf area, with the power model using the product $\left(\mathrm{L}^{*} \mathrm{~W}\right)$ being the best.

The most suitable equation for estimating leaf area of E. citrifolium was $\hat{y}=0.5966 * \mathrm{LW}^{1.0181}$.

RESUMO: Erythroxylum citrifolium é uma espécie de planta neotropical com registros em todas as regiões do Brasil. A determinação da área foliar é de fundamental importância em estudos relacionados a propagação e crescimento vegetal. $\mathrm{O}$ objetivo foi obter uma equação que permita estimar a área foliar de $E$. citrifolium a partir de dimensões lineares do limbo foliar (comprimento e largura). Foram coletados 200 limbos foliares no Parque Estadual Mata do Pau-Ferro, Areia, Paraíba, Nordeste do Brasil. Os modelos empregados foram: linear, linear sem intercepto, quadrático, cúbico, potencial e exponencial. Os critérios utilizados para escolher o melhor modelo, teve como base o maior coeficiente de determinação $\left(\mathrm{R}^{2}\right)$, menor raiz do quadrado médio do erro (RMSE), menor critério de informação de Akaike (AIC), maior índice de concordância de Willmott $(d)$ e índice BIAS mais próximo de zero. Todos os modelos construídos podem estimar satisfatoriamente a área foliar de E. citrifolium, com coeficientes determinação acima de 0,9050, porém o modelo potencial utilizando o produto entre comprimento e largura $(\mathrm{L} * \mathrm{~W}) \hat{\mathrm{y}}=0,5966 * \mathrm{LW}^{1,0181}$ é o mais indicado, com os maiores valores de $\mathrm{R}^{2} \mathrm{e} d$, menores valores de RMSE e AIC, e índice BIAS mais próximo de zero.

PALAVRAS-CHAVE: Biometria. Método não-destrutivo. Equações alométricas. Erythroxylaceae.

\section{REFERENCES}

ASSIS, J. P.; LINHARES, P. C. F.; SOUZA, R. P.; PEREIRA, M. F. S.; ALMEIDA, A. M. B. Estimação da área foliar da "jitirana" (Merremia aegyptia (L.) Urban), através de modelos de regressão para Mossoró - RN. Revista Verde de Agroecologia e Desenvolvimento Sustentável, v. 10, n. 4, p. 75-81, 2015. http://dx.doi.org/10.18378/rvads.v10i4.3872

BUTTARO, D.; ROUPHAEL, Y.; RIVERA, C. M.; COLLA, G.; GONNELLA, M. Simple and accurate allometric model for leaf area estimation in Vitis vinifera L. genotypes. Photosynthetica, v. 53, n. 3, p. 342348, 2015. https://doi.org/10.1007/s11099-015-0117-2 
CANDIDO, W. S.; COELHO, M. F. B.; MAIA, S. S. S.; CUNHA, C. S. M.; SILVA, R. C. P. Modelo para estimar a área foliar de Combretum leprosum Mart. Acta Agronômica, v. 62, n. 1, p. 37-41, 2013.

CARGNELUTTI FILHO, A.; TOEBE, M.; BURIN, C.; FICK, A. L.; CASAROTTO, G. Estimativa da área foliar de nabo forrageiro em função de dimensões foliares. Bragantia, v. 71, n. 1, p. 47-51, 2012. https://doi.org/10.1590/S0006-87052012000100008

CARGNELUTTI FILHO, A.; TOEBE, M.; ALVES, B. M.; BURIN, C.; KLEINPAUL, J. A. Estimação da área foliar de canola por dimensões foliares. Bragantia, v. 74, n. 2, p. 139-148, $2015 \mathrm{a}$.

http://dx.doi.org/10.1590/S0006-87052012000100008

CARGNELUTTI FILHO, A. C.; TOEBE, M.; ALVES, B.; BURIN, C. Estimativa da área foliar de feijão guandu por dimensões foliares. Ciência Rural, v. 45, n. 1, p. 1-8, 2015b. http://dx.doi.org/10.1590/0103$8478 \mathrm{cr} 20140551$

CARVALHO, J. O.; TOEBE, M.; TARTAGLIA, F. L.; BANDEIRA, C. T.; TAMBARA, A. L. Leaf area estimation from linear measurements in different ages of Crotalaria juncea plants. Anais da Academia Brasileira de Ciências, v. 89, n. 3, p. 1851-1868, 2017. http://dx.doi.org/10.1590/0001-3765201720170077

DAN, G.; CASTELLAR, A. Plantas medicinais com atividade antirretroviral. Alumni, v. 3. n. 6, p. 8-24, 2015.

ERLACHER, W. A.; OLIVEIRA, F. L.; FIALHO, G. S.; SILVA, D. M. N.; CARVALHO, A. H. O. Models for estimating yacon leaf area. Horticultura Brasileira, v. 34, n. 3, p. 422-427, 2016.

http://dx.doi.org/10.1590/S0102-05362016003019

FLORIANO, E. P.; MÜLLER, I.; FINGER, C. A. G.; SCHNEIDER, P. R. Ajuste e seleção de modelos tradicionais para série temporal de dados de altura de árvores. Ciência Florestal, v. 16, p.177-199, 2006. http://dx.doi.org/10.5902/198050981898

FRANCISCO, J. P.; DIOTTO, A. V.; FOLEGATTI, M. V.; SILVA, L. D. B.; PIEDADE, S. M. S. Estimativa da área foliar do abacaxizeiro cv. Vitória por meio de relações alométricas. Revista Brasileira de

Fruticultura, v. 36, n. 2, p. 285-293, 2014. http://dx.doi.org/10.1590/0100-2945-216/13

GANESHAMURTHY, A. N.; RAVINDRA, V.; VENUGOPALAN, R.; MATHIAZHAGAN, M.; BHAT, R. $\mathrm{M}$. Biomass distribution and development of a allometric equations for non-destructive estimation of carbon sequestration in Grafted Mango Trees. Journal of Agricultural Science, v. 8, n. 8, p. 201-211, 2016. http://dx.doi.org/10.5539/jas.v8n8p201

GONZÁLEZ-GUEVARA, J. L.; GONZÁLEZ-LAVAUT, J. A.; PINO-RODRÍGUEZ, S.; GARCÍA-TORRES, M.; CARBALLO-GONZÁLEZ, M. T.; ECHEMENDIA-ARANA, O. A.; MOLINA-TORRES, J.; PRIETOGONZÁLEZ, S. Phytochemical screening and in vitro antiherpetic activity of four Erythroxylum species. Acta Farmacéutica Bonaerense, v. 23, n. 4, p. 506-509, 2004.

HINNAH, D. H.; HELDWEIN, A. B.; MALDANER, I. C.; LOOSE, L. H.; LUCAS, D. D. P.; BORTOLUZZI, M. P. Estimativa da área foliar da berinjela em função das dimensões foliares. Bragantia, v. 73, n. 3, p. 213218, 2014. http://dx.doi.org/10.1590/1678-4499.0083

HOZUMI, T.; MATSUMOTO, T.; OOYAMA, H.; MAMBA, T.; SHIRAKI, K.; HATTORI, M.; KUROKAWA, M.; KADOTA, S. Antivaral agent containing crude drug., Antivaral agent containing crude drug. United State Patent No. US 5,411,733, 1995.

JADOSKI, S. O.; LOPES, É. C.; MAGGI, M. F.; SUCHORONCZEK, A.; SAITO, L. R.; DENEGA, S. Método de determinação da área foliar da cultivar de batata Ágata a partir de dimensões lineares. Semina, v. 33, n. 6, p. 2545-2554, 2012. https://doi.org/10.5433/1679-0359.2012v33Supl1p2545 
JANSSEN, P. H. M.; HEUBERGER, P. S. C. Calibration of process - oriented models. Ecological Modelling, v. 83, n. 1-2, p. 55-56, 1995. https://doi.org/10.1016/0304-3800(95)00084-9

KERAMATLOU, I.; SHARIFANI, M.; SABOURI, H.; ALIZADEH, M.; KAMKAR, B. A simple linear model for leaf area estimation in Persian walnut (Juglans regia L.). Scientia Horticulturae, v. 184, n. 1, p. 36-39, 2015. https://doi.org/10.1016/j.scienta.2014.12.017

LEITE, H. G.; ANDRADE, V. C. L. Um método para condução de inventários florestais sem o uso de equações volumétricas. Revista Árvore, v. 26, n. 3, p. 321-328, 2002. http://dx.doi.org/10.1590/S010067622002000300007

LEITE, M. L. M. V.; LUCENA, L. R. R.; SÁ JÚNIOR, E. H.; CRUZ, M. G. Estimativa da área foliar em Urochloa mosambicensis por dimensões lineares. Revista Agropecuária Técnica, v. 38, n. 1, p. 9-16, 2017. https://doi.org/10.25066/agrotec.v38i1.32041

LOIOLA, M. I. B.; AGRA, M. F.; BARACHO, G. S.; QUEIROZ, R. T. Flora da Paraíba, Brasil: Erythroxylaceae Kunth. Acta Botanica Brasilica, v. 21, n. 2, p. 473-487, 2007. http://dx.doi.org/10.1590/S0102-33062007000200020

LOIOLA, M. I. B.; COSTA-LIMA, J. L. Erythroxylaceae. In: Lista de espécies da flora do Brasil. Jardim Botânico do Rio de Janeiro, 2015. Disponível em: http://floradobrasil.jbrj.gov.br/jabot/floradobrasil/FB7680. Acesso em: 01 de fevereiro de 2018.

MALAGI, G.; CITADIN, I.; SCARIOT, S.; REIS, L. Non-destructive method for leaf area determination of grapevine 'brs-violeta' cultivar. Revista Brasileira de Fruticultura, v. 32, n. 4, p. 1250-1254, 2010. http://dx.doi.org/10.1590/S0100-29452011005000005

MATSUSE, I. T.; LIM, Y. A.; HATTORI, M.; CORREA, M.; GUPTA, M. P. A search for anti-viral properties in Panamanian medicinal plants: The effects on HIV and its essential enzymes. Journal of Ethnopharmacology, v. 64, n. 1, p. 15-22, 1999. https://doi.org/10.1016/S0378-8741(98)00099-3

MOTA, C. S.; LEITE, H. G.; CANO, M. A. O. Equações para estimar área foliar de folíolos de Acrocomia aculeta. Pesquisa Florestal Brasileira, v. 34, n. 79, p. 217-224, 2014.

https://doi.org/10.4336/2014.pfb.34.79.684

OLIVEIRA, R. L. L.; MOREIRA, A. R.; COSTA, A. V. A.; SOUZA, L. C.; LIMA, L. G. S.; SILVA, R. T. L. Modelos de determinação não destrutiva de área foliar de feijão caupi Vigna unguiculata (L.). Global Science and Technology, v. 8, n. 2, p. 17-27, 2015. https://doi.org/10.14688/1984-3801/gst.v8n2p17-27

OLIVEIRA, O. S.; SILVA, W.; COSTA, A. A. M.; SCHMILDT, E. R.; VITÓRIA, E. L. Leaf area estimation in litchi by means of allometric relationships. Revista Brasileira de Fruticultura, v. 39, n. Spe, p. 1-6, 2017. http://dx.doi.org/10.1590/0100-29452017403

PEEL, M. C.; FINLAYSON, B. L.; McMAHON, T. A. Updated world map of the Köppen-Geiger climate classification. Hydrology and Earth System Sciences, v. 11, p. 1633-1644, 2007.

https://doi.org/10.5194/hess-11-1633-2007

PEZZINI, R. V.; CARGNELUTTI FILHO, A.; ALVES, B. M.; FOLLMANN, D. N.; KLEINPAUL, J. A.; WARTHA, C. A.; SILVEIRA, D. L. Models for leaf area estimation in dwarf pigeon pea by leaf dimensions. Bragantia, v. 77, n. 2, p. 221-229, 2018. http://dx.doi.org/10.1590/1678-4499.2017106 (conferir se esta no texto)

PLOWMAN, T.; HENSOLD, N. Names, types and distribution of neotropical species of Erythroxylum (Erythroxylaceae). Brittonia, v. 56, n. 1, p. 1-53, 2004. https://doi.org/10.1663/0007196X(2004)056[0001:NTADON]2.0.CO;2 
POMPELLI, M. F.; ANTUNES, W. C.; FERREIRA, D. T. R. G.; CAVALCANTE, P. G. S.; WANDERLEYFILHO, H. C. L.; ENDRES, L. Allometric models for non-destructive leaf area estimation of Jatropha curcas. Biomass and Bioenergy, v. 36, p. 77-85, 2012. https://doi.org/10.1016/j.biombioe.2011.10.010

QUEIROZ, J. E.; SILVA, G. H.; SOUZA NETO, A. G. Avaliação estatística da área foliar através de modelos de equações em duas espécies florestais. Revista Verde de Agroecologia e Desenvolvimento Sustentável, v. 8, n. 1, p. 146-153, 2013.

R CORE TEAM. R: A language and environment for statistical computing. Vienna: R Foundation for Statistical Computing, 2018.

RIBEIRO, J. E. S.; BARBOSA, A. J. S.; ALBUQUERQUE, M. B. Leaf Area Estimate of Erythroxylum simonis Plowman by Linear Dimensions. Floresta e Ambiente, v. 25, n. 2, p. 1-7, $2018 \mathrm{a}$.

http://dx.doi.org/10.1590/2179-8087.010817

RIBEIRO, J. E. S.; BARBOSA, A. J. S.; LOPES, S. F.; PEREIRA, W. E.; ALBUQUERQUE, M. B. Seasonal variation in gas exchange by plants of Erythroxylum simonis Plowman. Acta Botanica Brasilica, v. 32, n. 2, p. 287-296, 2018b. http://dx.doi.org/10.1590/0102-33062017abb0240

RIBEIRO, J. E. S.; COÊLHO, E. S.; FIGUEIREDO, F. R. A.; PEREIRA, W. E.; ALBUQUERQUE, M. B. Leaf area estimation for Psychotria carthagenensis and Psychotria hoffmannseggiana as a function of linear leaf dimensions. Acta Scientiarum. Biological Sciences, v. 41, p. 1-8, 2019.

https://doi.org/10.4025/actascibiolsci.v41i1.43494

SCHMILDT, E. R.; HUESO, J. J.; CUEVAS, J. Allometric models for determining leaf area of vine 'Sugraone'. Ciência e Técnica Vitivinícola, v. 29, n. 10, p. 61-81, 2014.

https://doi.org/10.17660/th2017/72.1.2

SCHMILDT, E. R.; NEGRIS, F. S.; CESANA JUNIOR, E.; SCHMILDT, O.; ALEXANDRE, R. S. Equações para estimar área foliar de maracujá-amarelo. Nucleus, v. 13, n. 1, p. 97-104, 2016.

http://dx.doi.org/10.3738/1982.2278.1461

SILVA, G. H.; QUEIROZ, J. E.; NETO, A. G. S. Avaliação da área foliar de três espécies florestais ocorrentes no semiárido paraibano (Amburana cearenses, Caesalpinia ferrea, Caesalpinia pyramidalis). Revista de Biologia e Farmácia, v. 9, n. 3, p. 01-11, 2013.

SOUZA, M. C.; HABERMANN, G. Non-destructive equations to estimate leaf area of Styrax pohlii and Styrax ferrugineus. Brazilian Journal of Biology, v. 74, n. 1, p. 222-225, 2014. http://dx.doi.org/10.1590/15196984.17012

TOEBE, M.; CARGNELUTTI FILHO, A.; BURIN, C.; FICK, A. L.; NEU, I. M. M.; CASAROTTO, G.; ALVES, B. M. Modelos para a estimação da área foliar de feijão de porco por dimensões foliares. Bragantia, v. 71, n. 2, p. 37-41, 2012. http://dx.doi.org/10.1590/S0006-87052012005000010

WILLMOTT, C. J.; ACKLESON, S. G.; DAVIS, J. J.; FEDDEMA, K. M.; KLINK, D. R. Statistics for the evaluation and comparison of models. Journal of Geophysical Research, v. 90, n. C5, p. 8995-9005, 1985. https://doi.org/10.1029/JC090iC05p08995

ZHANG, L.; PAN, L. Allometric models for leaf area estimation across different leaf-age groups of evergreen broadleaved trees in a subtropical forest. Photosynthetican, v. 49, n. 2, p. 219-226, 2011.

https://doi.org/10.1007/s11099-011-0027-x 